Citation: Simsar, Y. (2021). An investigation of pre-school education policies in Turkey between 2000-2019 according to teachers' views. International Journal of Scholars in Education, 4(2), 228-245. doi:10.52134/ueader.1009514

\title{
An Investigation of Pre-school Education Policies in Turkey Between 2000-2019 According to Teachers' Views *
}

\author{
Yusuf SiMSAR**
}

\begin{abstract}
This study aims to examine pre-school teachers' views about the policies made in Turkey for the development of pre-school education between the years 2000-2019. In line with the purpose of the study, phenomenological research, one of the qualitative research methods, was used. In the study, semistructured interview questions were determined as a data collection tool, and the study was carried out with 25 pre-school teachers. When the results of the data analysis are examined, it is stated that the prevalence of pre-school education has increased as a result of the policies made by teachers. In this direction, the resources for pre-school education are provided, and the child is taken to the centre of education due to the education policies. However, it was stated that different problems (such as education periods, lack of auxiliary personnel, lack of materials in the classrooms, excess classroom sizes) were observed in the following years, and policies should regulate these. Suggestions were made in line with the findings of the study.
\end{abstract}

Keywords: Educational policies, Phenomenological research, Pre-school education, Pre-school teachers.

\section{0-2019 Yılları Arası Türkiye'de Yapılan Okul Öncesi Eğitim Politikalarının Öğretmen Görüşlerine Göre İncelenmesi}

Öz: Bu çalışmanın amacı 2000-2019 yılları arasında okul öncesi eğitimin geliştirilmesi adına Türkiye'de yapılan politikalar hakkında okul öncesi öğretmen görüşlerinin incelenmesidir. Çalışmanın amacı doğrultusunda nitel araştırma yöntemlerinden olgubilim araştırması kullanılmıştır. Çalışmada veri toplama aracı olarak yarı yapılandırılmış görüşme soruları belirlenmiş ve çalışma 25 okul öncesi öğretmeni ile gerçekleştirilmiştir. Veri analizleri sonucunda ortaya çıkan sonuçlar incelendiğinde, öğretmenlerin yapılan politikalar sonucunda okul öncesi eğitimin yaygınlaşmasının artı̆̆ bu doğrultuda okul öncesi eğitime yönelik kaynakların sağlandığı ve eğitim politikaları sonucunda çocuğun eğitimin merkezine alındığı belirtilmiştir. Ancak ilerleyen yıllarda farklı sorunların (eğitim süreleri, yardımcı personel eksikliği, sınıflardaki materyal eksiklikleri, sınıf mevcutlarının fazlalığı, gibi) gözlemlendiği ve politikalarla bunların düzenlenmesi gerektiği belirtilmiştir. Çalışmanın bulguları doğrultusunda öneriler sunulmuștur.

Anahtar Kelimeler: Eğitim politikaları, Olgubilim araştırması, Okul öncesi eğitim, Okul öncesi öğretmenleri.

\footnotetext{
* This article was produced from the author's Master's thesis. The ethical permission of this study was recieved from the Research Ethics Committee of Kahramanmaraş Sütçü İmam University (Date 26.12.2019, number 2019/35).

** M. Ed., Ministry of National Education, ORCID: 0000-0001-9679-5263 e-mail: yusufsimsar@ hotmail.com
} 


\section{Introduction}

Education is one of the essential processes that build the future of a society in line with the goals of that society. Education, the primary source of the development of societies, is the locomotive that will lead society to its goals. Countries that know that education is essential to give importance to all the elements involved in the education process and encourage them in every field. Education can also be defined as providing the desired behavioural change in the individual. One of the most critical elements of these processes is the schools where education is applied first-hand. Pre-school education, the first step of education, is the day the child is born to the day he starts primary education. In this process, the child's physical, cognitive, social, psychomotor and language development is completed to a large extent. In order to ensure that children have the desired behavioural characteristics, it is necessary to know their developmental characteristics well (Alisinanoğlu \& Kesicioğlu, 2010). Otherwise, many difficulties may be encountered, the upbringing of the child may be left to chance, and the child may be harmed without realizing it. From this point of view, the education is given in the preschool period, which includes many critical periods, is very important (Aral, Kandir, \& CanYaşar, 2003).

The pre-school period is when learning is the fastest and most intense, basic skills and habits are acquired in all developmental areas, and cognitive abilities are rapidly developed and shaped (Arslan-Karakuş, 2008; Bee \& Boyd, 2009; Oktay, 2004). Meeting the needs of the child, supporting his/her development in all aspects and ensuring that he/she is prepared for life in the best way can be achieved with a qualified pre-school education that will be offered to $\mathrm{him} / \mathrm{her}$ in these early years, and pre-school education is vital for the child's healthy development in all areas (Aslanargun \& Tapan, 2015; Gültekin-Akduman, Günindi, \& Türkoğlu, 2015; Kalkan \& Akman, 2009; Simsar, 2021a).

In the pre-school period, the brain continues to develop rapidly, and this period is also the period when advances in brain development are most open to the effects of the environment. Thus, the environment is one of the factors that profoundly affect the child's general development and learning motivation in these early years (Simsar, 2021b). How many the child can explore, what he can learn and how fast he can learn; is closely related to how supportive the child's environment is and what opportunities are offered to the child (Bee \& Boyd, 2009). Due to this rapid brain development in the first six years of life and the associated physical growth and maturation, children grow up very quickly and begin to become physically and cognitively competent in a short time (Bee \& Boyd, 2009; Santrock, 2012). Thanks to the quality pre-school education opportunities that support this development and progress, the way for the child to realize his/her potential and be a productive member of the society is opened (Bekman \& Gürlesel, 2005).

For pre-school education, each country takes various steps to gain social and cultural values. Regarding the inequality of opportunity in education, which is included in our country's 42nd article of the 1982 constitution, "No one can be deprived of the right to education and training. The scope of the right to education shall be determined by law and regulation. Primary education is compulsory for all citizens, male and female, and is free in public schools." statements are included. In addition, different support programs have been tried to be implemented for children from regions with low socioeconomic levels to ensure equality of opportunity in education. However, it is seen that the importance of pre-school education in our country has been realized late compared to other countries and it has been tried to organize preschool education with the policies made since 2000. However, knowing how much the studies are understood by the "teacher", who is the cornerstone of this educational process, and seeing how much they are reflected in the practices is considered as the first process that should be done before creating a new policy. Every country gives importance to pre-school education and 
allocates more resources to this field with different education policies in order to provide the human resources it will need, in line with the importance it attaches to pre-school education, which is the first step of education, in order to guarantee its future (Albrecht \& Miller, 2004). Therefore, many studies have been carried out on Pre-School Education Policies between 20002019 in our country for the primary education of pre-school children, which is the most crucial step of education. This research aims to examine the Pre-School Education Policies between the years 2000-2019 and reveal what pre-school teachers' views are on this issue. For this purpose, answers to the following questions were sought:

1- What policies were produced regarding pre-school education between 2000-2019?

2- What are the views of pre-school teachers about the steps taken regarding Pre-School Education between 2000-2019?

\section{Method}

In the research method part, detailed explanations are given under the titles of research model, study group, data collection, and analysis.

\section{Model of the Research}

This research aims to reveal the opinions of pre-school teachers about pre-school education policies between 2000-2019. In line with the purpose of the study, phenomenology design, one of the qualitative research methods, was used in this study. The phenomenology design focuses on phenomena that we are aware of but do not have an in-depth and detailed understanding of (Yıldırım \& Şimşek, 2013). Yıldırım and Şimşek (2013) explained their phenomenology studies as creating a suitable research ground for studies that aim to investigate the phenomena that are not entirely foreign to us and that we cannot fully comprehend. In this direction, it is thought that the phenomenology design is appropriate to reveal the views of preschool teachers about pre-school education policies and changes in policies.

\section{Working Group}

In this research, 25 pre-school teachers in Kahramanmaraş Province Türkoğlu District were included in the study voluntarily as the study group. The demographic characteristics of the study group participating in the research are given in the table below:

Table 1

Demographic Characteristics of the Study Group

\begin{tabular}{cccccc}
\hline Participants & Gender & Age & Seniority & $\begin{array}{c}\text { Educational } \\
\text { Status }\end{array}$ & Branch \\
\hline T1 & Male & 31 & 9 & Licence & Pre-School Teacher \\
T2 & Female & 42 & 16 & Licence & Pre-School Teacher \\
T3 & Male & 43 & 18 & Licence & Pre-School Teacher \\
T4 & Female & 24 & 3 & Licence & Pre-School Teacher \\
T5 & Female & 40 & 14 & Licence & Pre-School Teacher \\
T6 & Male & 27 & 3 & Licence & Pre-School Teacher \\
T7 & Male & 23 & 2 & Licence & Pre-School Teacher \\
T8 & Female & 36 & 13 & Licence & Pre-School Teacher \\
T9 & Female & 24 & 3 & Licence & Pre-School Teacher \\
T10 & Female & 30 & 5 & Licence & Pre-School Teacher \\
\hline
\end{tabular}




\begin{tabular}{lcccll}
\hline T11 & Male & 30 & 7 & Licence & Pre-School Teacher \\
T12 & Female & 36 & 10 & Licence & Pre-School Teacher \\
T13 & Female & 27 & 6 & Licence & Pre-School Teacher \\
T14 & Male & 30 & 8 & Licence & Pre-School Teacher \\
T15 & Female & 36 & 11 & Licence & Pre-School Teacher \\
T16 & Female & 28 & 4 & Licence & Pre-School Teacher \\
T17 & Female & 29 & 5 & Licence & Pre-School Teacher \\
T18 & Female & 26 & 3 & Licence & Pre-School Teacher \\
T19 & Female & 32 & 9 & Licence & Pre-School Teacher \\
T20 & Female & 28 & 5 & Licence & Pre-School Teacher \\
T21 & Male & 31 & 6 & Licence & Pre-School Teacher \\
T22 & Female & 28 & 5 & Licence & Pre-School Teacher \\
T23 & Female & 31 & 8 & Licence & Pre-School Teacher \\
T24 & Female & 30 & 8 & Licence & Pre-School Teacher \\
T25 & Male & 29 & 7 & Licence & Pre-School Teacher \\
\hline
\end{tabular}

\section{Data Collection Tool}

The data of the research were obtained by interview. A structured formula was used through interviews. Six open-questions with semi-reflexive questions were asked by taking into account the form that will be grown by the researcher and making use of the field. The completion of the preparations for the place in the interview forms will be carried out by two students (in the pre-school education area and the preparatory course). Information for experts is given.

\section{Data Collection}

In order to collect the research data, 25 pre-school teachers in Türkoğlu District in the research sample were interviewed on different days and times between 02/12/2019 and $15 / 01 / 2020$ in the schools where the teachers work. Before the interview, the participants were informed about the purpose of the study and the confidentiality of the interview, and the interviews were carried out after obtaining a consent form about whether they volunteered to participate. The interviews were conducted in the form of a conversation with the participants, and the researcher recorded the participants' answers by writing them on the forms. The interview with each person in the research sample lasted an average of 20 minutes. Although the questions posed to the participants during the interview were determined in advance, they were asked to ask differently without changing the content of the questions when necessary, and from time to time, they were asked again.

The following questions were asked to the pre-school teachers in the sample group at the interview stage.

1. How do you evaluate the policies in the field of pre-school education after 2000 ?

2. What do you think is the best step taken in pre-school education?

3. What are the shortcomings of the pre-school education policies developed between 2000-2019?

4. What are the highlights of the pre-school education policies developed between 2000-2019 in your opinion? 
5. Which policies should be implemented as a priority for developing pre-school education?

6. What should be done to develop pre-school education in our country?

\section{Data Analysis}

The content analysis method, which requires the conceptualization of the data obtained from the interviews with the participants, and then the logical arrangement according to the emerging concepts and the Determination of the themes that explain the data accordingly, was used. The data were read and coded by the researcher, the researcher did a second reading, and at the end of the second reading, the concepts used to encode some data parts were changed. It has been studied under which themes the codes can be collected, and the themes that may occur were determined. After the researcher did the coding and theme creation work, coding on all the data and creating a theme from the codes were carried out by an expert in the field and an academician who has competence in content analysis methods. The codes and themes created by the researcher were compared with the codes and themes created by the expert.

\section{Findings}

\section{Evaluation of Policies in Pre-School Education After 2000}

The themes and codes related to the themes obtained as a result of the analysis of the answers given to the question "How do you evaluate the policies in the field of preschool education after 2000?" are given in Table 2.

Table 2.

Teachers' Views on Policies in Pre-School Education After 2000

\begin{tabular}{|c|c|c|c|c|}
\hline Theme & Code & Example Sentences & $\mathbf{f}$ & $\%$ \\
\hline \multirow{5}{*}{$\begin{array}{l}\text { Education } \\
\text { Policies }\end{array}$} & $\begin{array}{l}\text { Schooling has } \\
\text { become } \\
\text { widespread }\end{array}$ & $\begin{array}{l}\text { It started in the form of increasing the schooling } \\
\text { rate. (T1) } \\
\text { I think that the schooling rate has been } \\
\text { increased. (T15) } \\
\text { I support pre-school education dissemination } \\
\text { efforts. (T4) } \\
\text { Pre-School Education was tried to be } \\
\text { widespread. (T12) }\end{array}$ & 12 & 48.00 \\
\hline & $\begin{array}{l}\text { Child-centred } \\
\text { Education }\end{array}$ & $\begin{array}{l}\text { Efforts were made to put the child in the centre } \\
\text { and actively train him. (T1) (T11) } \\
\text { I support education programs with child-centred } \\
\text { games. (T24) }\end{array}$ & 4 & 16.00 \\
\hline & $\begin{array}{l}\text { Increasing } \\
\text { Physical } \\
\text { Facilities }\end{array}$ & $\begin{array}{l}\text { It is essential to increase kindergartens. (T22) } \\
\text { Increasing the number of educational } \\
\text { institutions is one of the positive practices (T15) }\end{array}$ & 3 & 12.00 . \\
\hline & $\begin{array}{l}\text { Emphasis on Pre- } \\
\text { School Education }\end{array}$ & $\begin{array}{l}\text { I think that the importance given to pre-school } \\
\text { education has increased(T13) } \\
\text { More importance has been given to pre-school } \\
\text { education. (T25) }\end{array}$ & 3 & 12.00 \\
\hline & Sourcing & $\begin{array}{l}\text { Expenditures for education have been increased. } \\
\text { (T12) } \\
\text { Financial support was provided by giving } \\
\text { importance to pre-school education. (T8) }\end{array}$ & 3 & 12.00 \\
\hline
\end{tabular}




\begin{tabular}{|c|c|c|c|}
\hline Resources & $\begin{array}{l}\text { I think that a sufficient budget is not allocated } \\
\text { because it is not included in the scope of } \\
\text { compulsory education (T17) } \\
\text { I think that the budget for pre-school is not } \\
\text { enough. (T23) }\end{array}$ & 2 & 8.00 \\
\hline $\begin{array}{l}\text { The Decreased } \\
\text { Social Value is } \\
\text { Given to the } \\
\text { Teacher }\end{array}$ & $\begin{array}{l}\text { I think that the value given to the teacher has } \\
\text { decreased. (T21) } \\
\text { I do not think that the teacher is valued enough } \\
\text { (T25) }\end{array}$ & 2 & 8.00 \\
\hline $\begin{array}{l}\text { Infrastructure } \\
\text { Problem }\end{array}$ & $\begin{array}{l}\text { It is the work done without an infrastructure. } \\
\text { (T5) } \\
\text { The school problem has been solved primarily } \\
\text { in large settlements, but there are still not } \\
\text { enough schools in villages and towns. (T17) }\end{array}$ & 2 & 8.00 \\
\hline $\begin{array}{l}\text { Education with } \\
\text { Games }\end{array}$ & $\begin{array}{l}\text { Education started to be done with games rather } \\
\text { than memorization. (T7) }\end{array}$ & 1 & 4.00 \\
\hline Staff Quality & $\begin{array}{l}\text { I think that employees should receive better } \\
\text { training. (T20) }\end{array}$ & 1 & 4.00 \\
\hline $\begin{array}{l}\text { Family } \\
\text { Involvement }\end{array}$ & $\begin{array}{l}\text { Programs that take the family into account were } \\
\text { implemented in Pre-school education. (T9) }\end{array}$ & 1 & 4.00 \\
\hline $\begin{array}{l}\text { Ignoring Pre- } \\
\text { School Education }\end{array}$ & $\begin{array}{l}\text { I think pre-school education is not given } \\
\text { importance. (T16) }\end{array}$ & 1 & 4.00 \\
\hline
\end{tabular}

When Table 2 is examined, it is seen that the teachers in the study group mainly mentioned the dissemination of schools $(48 \%)$ and the minor emphasis on pre-school education, staff quality, family participation, education with games (4\%) for the evaluation of policies between the years 2000-2019 has been reached.

When Table 2 is examined for the different findings related to the theme of education policies, it is seen that the child-centred education is $16 \%$, the physical opportunities are increased, the pre-school education is given importance, the resource is $12 \%$, the resource is not provided, the social value given to the teacher decreases and the infrastructure problem is related to the issues. Teachers expressed their opinions at the rate of $8 \%$. Some examples of teachers' views are given below:

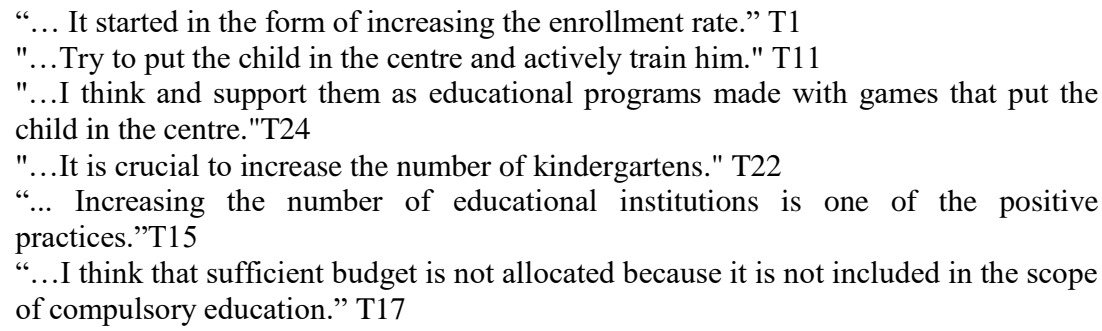

\section{The Most Beautiful Change Made in Pre-School Education Between 2000-2019}

In line with the purpose of the research, to determine the participants' views about the best change in pre-school education, "What do you think is the best step taken in the field of pre-school education?" The question was asked, and the findings regarding the content analysis for the answers received are given in Table 3. 
Table 3

Teachers' Opinions On The Best Step Taken In The Field of Pre-School Education

\begin{tabular}{|c|c|c|c|c|}
\hline Theme & Code & Example Sentences & f & $\%$ \\
\hline \multirow{9}{*}{$\begin{array}{l}\text { The Best Step } \\
\text { Made in } \\
\text { Education }\end{array}$} & $\begin{array}{l}\text { Compulsory Pre- } \\
\text { School Education }\end{array}$ & $\begin{array}{l}\text { Studies on making pre-school education } \\
\text { compulsory. (T9) } \\
\text { Compulsory pre-school education (T4) }\end{array}$ & 8 & 32.00 \\
\hline & $\begin{array}{l}\text { Expansion of } \\
\text { Schooling }\end{array}$ & $\begin{array}{l}\text { Pre-school education was expanded. } \\
\text { (T16) } \\
\text { Dissemination of pre-school education. } \\
\text { (T16) } \\
\text { Studies to increase the schooling rate. } \\
\text { (T14) }\end{array}$ & 5 & 20.00 \\
\hline & $\begin{array}{l}\text { Pre-School } \\
\text { Education } \\
\text { Program } \\
\end{array}$ & $\begin{array}{l}\text { Preparation of Pre-school education } \\
\text { program. (T22) }\end{array}$ & 4 & 16.00 \\
\hline & $\begin{array}{l}\text { Duplication of } \\
\text { Pre-School } \\
\text { Education } \\
\text { Institutions }\end{array}$ & $\begin{array}{l}\text { Opening kindergarten in all school } \\
\text { types. (T8,) } \\
\text { Reproduction of the number of } \\
\text { kindergartens. (T23) }\end{array}$ & 3 & 12.00 \\
\hline & Personal Number & $\begin{array}{l}\text { Increasing the number of kindergarten } \\
\text { teachers. (T8,) }\end{array}$ & 2 & 8.00 \\
\hline & Technology Use & $\begin{array}{l}\text { Establishing the E-okul system and } \\
\text { processing student information here. } \\
\text { (T11) } \\
\text { Ability to share events in EBA.(T17) }\end{array}$ & 2 & 8.00 \\
\hline & $\begin{array}{l}\text { Family } \\
\text { Involvement }\end{array}$ & $\begin{array}{l}\text { With the education calendar application, } \\
\text { family participation in education } \\
\text { increases. (T7) } \\
\text { Families begin to give importance to } \\
\text { Pre-School Education (T9) }\end{array}$ & 2 & 8.00 \\
\hline & $\begin{array}{l}\text { Child-Centred } \\
\text { Education }\end{array}$ & $\begin{array}{l}\text { It is the preparation of a child-centred } \\
\text { education program. (T20) }\end{array}$ & 1 & 4.00 \\
\hline & $\begin{array}{l}\text { School Age } \\
\text { Regulation }\end{array}$ & $\begin{array}{l}\text { Extending the Pre-School Education age } \\
\text { range. (T1) }\end{array}$ & 1 & 4.00 \\
\hline
\end{tabular}

When Table 3 is examined, it has been found that the teachers in the study group, in their views on the best step in pre-school education after 2000, mainly mentioned that preschool education should be compulsory with $32 \%$. The least stated opinion was school-age regulation with $4 \%$. When Table 3 is examined for the different findings related to the best step in education, the pre-school education program issue emerges as $20 \%$ with the spread of schooling. The proliferation of pre-school education institutions, on the other hand, is one of the issues mentioned about the best step made in pre-school education after 2000 with a rate of $12 \%$. The number of personnel, use of technology, and family involvement were mentioned at a rate of $8 \%$, while child-centred education and school-age regulation were mentioned at $4 \%$. Below are some quotations that may serve as examples of his explanations for The Most Beautiful Step Made in Pre-School Education After 2000.

"... Studies on making Pre-School Education compulsory." T9

"...Preparation of Pre-School Education Program.” T22

“... Opening kindergarten in all school types." T8,

"...It is the duplication of the number of kindergartens." T23. 


\section{Weaknesses of Pre-School Education Policies Developed Between 2000-2019}

In line with the purpose of the research, to present the participants' opinions about the deficiencies, they observed among the steps taken to ensure the development of pre-school education in our country, "What are the shortcomings of the pre-school education policies developed between 2000-2019?" The question was asked, and the findings regarding the content analysis for the answers received are shown in Table 4.

Table 4

Teachers' Opinions on the Deficiencies of Pre-School Education Policies Between 2000-2019

\begin{tabular}{|c|c|c|c|c|}
\hline Theme & Code & Example Sentences & $\mathbf{f}$ & $\%$ \\
\hline \multirow{12}{*}{$\begin{array}{l}\text { Weaknesses } \\
\text { of Education } \\
\text { Policies }\end{array}$} & Family Education & $\begin{array}{l}\text { Activities to change parents' attitudes } \\
\text { towards Pre-school Education. (T7) } \\
\text { Not providing family training to change } \\
\text { parent attitudes. (T10) }\end{array}$ & 5 & 20.00 \\
\hline & $\begin{array}{l}\text { Lack of Materials } \\
\text { in Classes }\end{array}$ & $\begin{array}{l}\text { Classes are insufficient in terms of materials. } \\
\text { (T4) } \\
\text { In-class material support is almost non- } \\
\text { existent. (T14) } \\
\text { There is a lack of materials in schools. (T16) }\end{array}$ & 5 & 20.00 \\
\hline & Class Sizes & $\begin{array}{l}\text { Crowded classrooms. (T2) } \\
\text { In some schools, the number of students is } \\
\text { low, and in some schools, it is very crowded. } \\
\text { (T8) } \\
\text { The number of students in the class is not at } \\
\text { the average level. (T11) } \\
\text { Class sizes are different. (T23) }\end{array}$ & 5 & 20.00 \\
\hline & $\begin{array}{l}\text { Pre-School } \\
\text { Education Is Not } \\
\text { Compulsory }\end{array}$ & $\begin{array}{l}\text { Pre-primary education is still not } \\
\text { compulsory. (T4) } \\
\text { Pre-school education is not compulsory. } \\
\text { (T15) }\end{array}$ & 3 & 12.00 \\
\hline & $\begin{array}{l}\text { The difficulty of } \\
\text { Implementation of } \\
\text { the Program }\end{array}$ & $\begin{array}{l}\text { Pre-school program is challenging to } \\
\text { implement. (T22) } \\
\text { The program is challenging to implement } \\
\text { considering the conditions of the schools. } \\
\text { (T2) }\end{array}$ & 3 & 12.00 \\
\hline & $\begin{array}{l}\text { Increasing Physical } \\
\text { Facilities }\end{array}$ & $\begin{array}{l}\text { Lack of school numbers. (T21) } \\
\text { An insufficient number of schools. (T11) } \\
\text { Inability to arrange physical areas. (T23) }\end{array}$ & 3 & 12.00 \\
\hline & $\begin{array}{l}\text { Lack of Auxiliary } \\
\text { Staff }\end{array}$ & $\begin{array}{l}\text { There is a lack of auxiliary personnel in } \\
\text { kindergartens. (T13) } \\
\text { There are not enough auxiliary personnel in } \\
\text { schools. (T16) }\end{array}$ & 3 & 12.00 \\
\hline & Lack of Resources & $\begin{array}{l}\text { Not enough resources. (T4) } \\
\text { The budget allocated for Pre-school } \\
\text { Education is meagre. (T15) }\end{array}$ & 2 & 8.00 \\
\hline & $\begin{array}{l}\text { Decreased Social } \\
\text { Value Given to } \\
\text { Teachers }\end{array}$ & $\begin{array}{l}\text { Decreased respect and value of the teacher. } \\
\text { (T6) } \\
\text { Not increasing the social value given to the } \\
\text { teacher. (T21) }\end{array}$ & 2 & 8.00 \\
\hline & $\begin{array}{l}\text { Absence of Lesson } \\
\text { Breaks }\end{array}$ & No breaks during training hours. (T10) & 2 & 8.00 \\
\hline & $\begin{array}{l}\text { Lack of Personal } \\
\text { Rights of Teachers }\end{array}$ & Lack of personal rights of teachers. (T25) & 1 & 4.00 \\
\hline & Teacher Quality & Inadequate training for teachers (T10) & 1 & 4.00 \\
\hline
\end{tabular}




\begin{tabular}{|c|c|c|c|}
\hline $\begin{array}{l}\text { Ignoring Preschool } \\
\text { Education }\end{array}$ & $\begin{array}{l}\text { The importance and necessity of pre-school } \\
\text { Education are not explained. (T21) }\end{array}$ & 1 & 4.00 \\
\hline $\begin{array}{l}\text { Opportunity } \\
\text { Equality }\end{array}$ & $\begin{array}{l}\text { Equality of opportunity in education could } \\
\text { not be achieved. (T4) }\end{array}$ & 1 & 4.00 \\
\hline $\begin{array}{l}\text { Early School } \\
\text { Starting Age }\end{array}$ & $\begin{array}{l}\text { The age for starting school for 36-month- } \\
\text { olds is very early. Children at this age need } \\
\text { to stay with their mothers. (T15) }\end{array}$ & 1 & 4.00 \\
\hline $\begin{array}{l}\text { The necessity of } \\
\text { Pre-School } \\
\text { Education }\end{array}$ & $\begin{array}{l}\text { The importance and necessity of pre-school } \\
\text { Education are not explained. (T11) }\end{array}$ & 1 & 4.00 \\
\hline $\begin{array}{l}\text { Educational Status } \\
\text { of Managers }\end{array}$ & $\begin{array}{l}\text { The administrators who will implement the } \\
\text { pre-school education program are not } \\
\text { educators. (T5) }\end{array}$ & 1 & 4.00 \\
\hline $\begin{array}{l}\text { In-Service Training } \\
\text { of Teachers }\end{array}$ & $\begin{array}{l}\text { In-service training given to pre-school } \\
\text { teachers is low. (T14) }\end{array}$ & 1 & 4.00 \\
\hline $\begin{array}{l}\text { Schooling Has } \\
\text { Become } \\
\text { Widespread } \\
\end{array}$ & $\begin{array}{l}\text { The schooling rate is still not at the desired } \\
\text { level. (T1) }\end{array}$ & 1 & 4.00 \\
\hline Technology Use & There is not enough content in EBA.(T14) & 1 & 4.00 \\
\hline $\begin{array}{l}\text { Providing Financial } \\
\text { Resources }\end{array}$ & $\begin{array}{l}\text { Pre-school education is still not supported by } \\
\text { the state at the desired level. (T11) }\end{array}$ & 1 & 4.00 \\
\hline
\end{tabular}

When Table 4 is examined, the questions asked to the teachers interviewed are: "What are the shortcomings of the pre-school education policies developed between 2000-2019?" Findings and comments about the question were discussed. In this theme, family education, lack of materials in the classrooms and class sizes appear the most mentioned topic, with $20 \%$ when the answers are given proportionate. It is understood that pre-school education is not compulsory, the program's implementation is complex, physical facilities are increased, and the lack of auxiliary personnel is the second most mentioned issue with $12 \%$. The lack of resources, the decrease in the teacher's social value, and the absence of lesson breaks are the third most mentioned issue with $8 \%$. After 2000 , different teachers' views on the deficiencies of pre-school education policies are $4 \%$, the lack of personal rights of teachers, the quality of teachers, the neglect of pre-school education, equal opportunities, early school starting age, the necessity of pre-school education, the education level of the administrators, the service level of the teachers. In-house education, widespread schooling, use of technology, and providing financial resources. The sentences to be given as examples of some of the teachers' views on this subject are as follows:

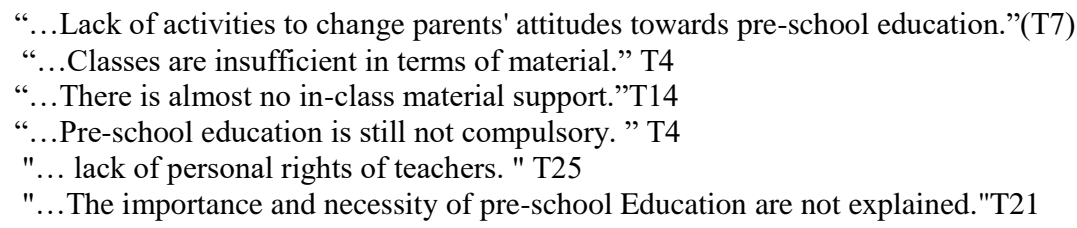

\section{Featured Issues in Pre-School Education Policies Developed Between 2000-2019}

In line with the purpose of the research, in order to present the opinions of the teachers about the prominent issues among the steps taken to ensure the development of pre-school education in our country, the participants were asked, "What are the prominent issues in the preschool education policies developed between 2000-2019?" The question was asked, and the findings regarding the content analysis for the answers received are shown in Table 5. 
Table 5

Teachers' Views on the Prominent Issues in Pre-school Education Policies After 2000

\begin{tabular}{|c|c|c|c|c|}
\hline Theme & Code & Example Sentences & $\mathbf{f}$ & $\%$ \\
\hline \multirow{11}{*}{$\begin{array}{l}\text { Featured Issues } \\
\text { in Education } \\
\text { Policies }\end{array}$} & $\begin{array}{l}\text { Expansion of } \\
\text { Schooling }\end{array}$ & $\begin{array}{l}\text { Dissemination of pre-school education. (T13) } \\
\text { Studies to increase the schooling rate. (T3) } \\
\text { Expansion of schooling (T12) } \\
\text { Increasing the schooling rate. (T14) }\end{array}$ & 7 & 28.00 \\
\hline & $\begin{array}{l}\text { Studies on } \\
\text { Compulsory } \\
\text { Pre-School } \\
\text { Education } \\
\end{array}$ & $\begin{array}{l}\text { Studies on making pre-school education } \\
\text { compulsory. (T24) } \\
\text { Compulsory pre-school education was coming to } \\
\text { the fore. (T15) }\end{array}$ & 6 & 24.00 \\
\hline & $\begin{array}{l}\text { Technology } \\
\text { Use }\end{array}$ & $\begin{array}{l}\text { Studies to benefit from developing technology. } \\
\text { (T6) } \\
\text { Establishing the e-school system and processing } \\
\text { student information here. (T18) }\end{array}$ & 3 & 12.00 \\
\hline & $\begin{array}{l}\text { Duplication of } \\
\text { Pre-School } \\
\text { Education } \\
\text { Institutions }\end{array}$ & $\begin{array}{l}\text { Opening kindergarten in all school types. (T7) } \\
\text { Reproduction of the number of kindergartens. } \\
\text { (T10) }\end{array}$ & 2 & 8.00 \\
\hline & $\begin{array}{l}\text { Student } \\
\text { Socialization } \\
\text { Studies }\end{array}$ & $\begin{array}{l}\text { Preparation of programs on the socialization of } \\
\text { the student. (T23) }\end{array}$ & 2 & 8.00 \\
\hline & $\begin{array}{l}\text { Personal } \\
\text { Number }\end{array}$ & $\begin{array}{l}\text { Increasing the number of kindergarten teachers. } \\
\text { (T19) }\end{array}$ & 1 & 4.00 \\
\hline & $\begin{array}{l}\text { Learning by } \\
\text { Doing }\end{array}$ & $\begin{array}{l}\text { More active learning of students with learning } \\
\text { by doing. (T1) }\end{array}$ & 1 & 4.00 \\
\hline & $\begin{array}{l}\text { Pre-school } \\
\text { Education } \\
\text { Program }\end{array}$ & $\begin{array}{l}\text { Preparation of pre-school education program. } \\
\text { (T22) }\end{array}$ & 1 & 4.00 \\
\hline & $\begin{array}{l}\text { The flexibility } \\
\text { of the Pre- } \\
\text { school } \\
\text { Education } \\
\text { Program }\end{array}$ & $\begin{array}{l}\text { The flexibility of the pre-school education } \\
\text { program(T11) }\end{array}$ & 1 & 4.00 \\
\hline & $\begin{array}{l}\text { The necessity } \\
\text { of Pre-school } \\
\text { Education }\end{array}$ & $\begin{array}{l}\text { The necessity of pre-school education has been } \\
\text { understood by society. (T8) }\end{array}$ & 1 & 4.00 \\
\hline & $\begin{array}{l}\text { Child-centred } \\
\text { Education }\end{array}$ & $\begin{array}{l}\text { It is the preparation of a child-centred education } \\
\text { program. (T24) }\end{array}$ & 1 & 4.00 \\
\hline
\end{tabular}

When Table 5 is examined regarding the teachers' views on the prominent issues in preschool education policies after 2000, the prevalence of schooling is the prominent issue with a rate of $28 \%$, followed by the studies that make pre-school education compulsory with a rate of $24 \%$ and the use of technology with a rate of $12 \%$. It is seen that the increase of pre-school education institutions and the socialization of the students take place at the rate of $8 \%$. After the 2000 s, teachers' opinions on the prominent issues in pre-school education policies included the number of personnel, learning by doing, pre-school education program, the flexibility of preschool education program, the necessity of pre-school education, and child-centred education at the rate of $4 \%$. Here are some sample sentences in the teachers' views on the prominent issues in pre-school education policies after the 2000s. "

“...Okul öncesi eğitimin yaygınlaştırılması.” T4

"... The efforts to make Pre-School Education compulsory.”T24

"...E-school system can be established, and student information can be processed here."T18

"...It is the reproduction of the number of kindergartens."T10 
“...Preparation of programs on the socialization of the student.”T23

"....Increasing the number of kindergarten teachers." T19

"...More active learning of students through learning by doing."T1

\section{Policies to be Implemented for the Development of Pre-School Education in Our Country}

In line with the purpose of the research, the participants were asked, "Which policies should be implemented as a priority for the development of pre-school education?" The question was asked, and the findings regarding the content analysis for the answers received are shown in Table 6.

Table 6

Teachers' Views on Which Policies Should Be Implemented Primarily for the development of Pre-School Education

\begin{tabular}{|c|c|c|c|c|}
\hline \multirow[t]{7}{*}{ Theme } & Code & Example Sentences & f & $\%$ \\
\hline & $\begin{array}{l}\text { Compulsory Pre- } \\
\text { School Education }\end{array}$ & $\begin{array}{l}\text { Pre-school education should be made } \\
\text { compulsory. (T3) }\end{array}$ & 7 & 28.00 \\
\hline & Sourcing & $\begin{array}{l}\text { The state should support pre-school } \\
\text { education. (T1) } \\
\text { The budget should be allocated for pre- } \\
\text { school education. (T12) }\end{array}$ & 6 & 24.00 \\
\hline & Family Education & $\begin{array}{l}\text { The number of activities to change parents' } \\
\text { attitudes towards pre-school education } \\
\text { should be increased. (T17) } \\
\text { Family training should be given to change } \\
\text { parent attitudes. (T10) }\end{array}$ & 4 & 16.00 \\
\hline & Opportunity Equality & $\begin{array}{l}\text { Equal opportunities should be provided in } \\
\text { education. (T4) }\end{array}$ & 4 & 16.00 \\
\hline & $\begin{array}{l}\text { Lack of Materials in } \\
\text { Classes }\end{array}$ & $\begin{array}{l}\text { Classes should be enriched in terms of } \\
\text { materials. (T13) } \\
\text { The lack of materials in schools should be } \\
\text { eliminated. (T11) }\end{array}$ & 3 & 12.00 \\
\hline & $\begin{array}{l}\text { Increasing Physical } \\
\text { Facilities }\end{array}$ & $\begin{array}{l}\text { The physical areas of the schools should be } \\
\text { arranged. (T14) }\end{array}$ & 3 & 12.00 \\
\hline \multirow{9}{*}{$\begin{array}{l}\text { Prospects } \\
\text { or } \\
\text { Educational } \\
\text { Policies }\end{array}$} & $\begin{array}{l}\text { Expansion of } \\
\text { Schooling }\end{array}$ & $\begin{array}{l}\text { The schooling rate should be increased. } \\
\text { (T16) }\end{array}$ & 3 & 12.00 \\
\hline & Teacher Quality & $\begin{array}{l}\text { The teachers who will implement the pre- } \\
\text { school Education program should be well } \\
\text { trained. (T16) }\end{array}$ & 2 & 8.00 \\
\hline & Class Sizes & $\begin{array}{l}\text { Class Availability should be reduced. (T2) } \\
\text { The number of students in the class } \\
\text { decreases the quality of education. (T1) }\end{array}$ & 2 & 8.00 \\
\hline & Auxiliary Staff & $\begin{array}{l}\text { Sufficient support staff should be available } \\
\text { in schools. (T17) }\end{array}$ & 2 & 8.00 \\
\hline & $\begin{array}{l}\text { Project Preparations } \\
\text { of Academicians }\end{array}$ & $\begin{array}{l}\text { Academicians at universities should } \\
\text { contribute to pre-school education by } \\
\text { preparing projects. (T9) }\end{array}$ & 1 & 4.00 \\
\hline & $\begin{array}{l}\text { Personal Rights of } \\
\text { Teachers }\end{array}$ & Teachers' rights need to be regulated. (T21) & 1 & 4.00 \\
\hline & $\begin{array}{l}\text { The difficulty of } \\
\text { Implementation of } \\
\text { the Program }\end{array}$ & $\begin{array}{l}\text { The pre-school program should be } \\
\text { reorganized. (T15) }\end{array}$ & 1 & 4.00 \\
\hline & $\begin{array}{l}\text { The necessity of Pre- } \\
\text { School Education }\end{array}$ & $\begin{array}{l}\text { The importance and necessity of pre-school } \\
\text { education should be explained. (T19) }\end{array}$ & 1 & 4.00 \\
\hline & $\begin{array}{l}\text { At least } 2 \text { Years of } \\
\text { Education }\end{array}$ & $\begin{array}{l}\text { Pre-school education should be at least two } \\
\text { years. (T14) }\end{array}$ & 1 & 4.00 \\
\hline
\end{tabular}




$\begin{array}{llll}\text { Lesson Breaks } & \begin{array}{l}\text { It is necessary to take a break during the } \\ \text { training hours. (T10) }\end{array} & 1 & 4.00\end{array}$

When Table 6 is examined, regarding the opinions of the teachers in the study group about which policies should be implemented as a priority for the development of pre-school education, the most pre-school education is compulsory (28\%) and the minor academics preparing projects, teachers' rights, school It has been reached that they mentioned the necessity of pre-education, at least two years of education and course breaks (4\%). When Table 1 is examined for the different findings related to the theme of priority expectations that need to be done, it is stated that providing resources is $24 \%$, family education, equality of opportunity is $16 \%$, lack of materials in the classrooms, increasing physical opportunities and expanding schooling is $12 \%$. While teacher quality, class sizes, and auxiliary personnel were mentioned at $8 \%$, it was seen that teachers' rights, the difficulty of the implementation of the program, the necessity of pre-school education, at least two years of education and class breaks were also mentioned at a rate of $4 \%$. Examples of teacher opinions on prominent topics are as follows:

“...Pre-school education should be made compulsory." T3

"...Pre-school education should be supported by the state." T1

“...A budget should be allocated for pre-school education." T12

“...The number of activities aimed at changing parents' attitudes towards pre-school sducation should be increased." T17

"...The enrollment rate needs to be increased." T16

“...The teachers who will implement the pre-school education program should be well trained."T20

\section{Development of Pre-School Education in Our Country}

In line with the purpose of the research, the participants were asked, "What should be done to develop pre-school education in our country?" The question was asked, and the findings regarding the content analysis for the answers received are shown in Table 7.

Table 7

Teachers' Views on What Should Be Done for the Development of Pre-School Education

\begin{tabular}{|c|c|c|c|c|}
\hline Theme & Code & Example Sentences & $\mathbf{f}$ & $\%$ \\
\hline \multirow{8}{*}{$\begin{array}{l}\text { Prospects for } \\
\text { the } \\
\text { Development of } \\
\text { Preschool } \\
\text { Education in } \\
\text { Our Country }\end{array}$} & $\begin{array}{l}\text { Expanding } \\
\text { Schooling }\end{array}$ & $\begin{array}{l}\text { Pre-school education needs to be expanded. } \\
\text { (T7) }\end{array}$ & 6 & 24.00 \\
\hline & Family Education & $\begin{array}{l}\text { It is necessary to organize some activities to } \\
\text { change parents' attitudes towards pre-school } \\
\text { Education. (T23) }\end{array}$ & 6 & 24.00 \\
\hline & $\begin{array}{l}\text { Elimination of } \\
\text { Material Needs }\end{array}$ & $\begin{array}{l}\text { Classes should be enriched in terms of } \\
\text { materials. (T2) } \\
\text { The lack of materials in schools should be } \\
\text { eliminated. (T8) }\end{array}$ & 6 & 24.00 \\
\hline & $\begin{array}{l}\text { Lack of Auxiliary } \\
\text { Staff }\end{array}$ & $\begin{array}{l}\text { It is necessary to increase the number of } \\
\text { auxiliary personnel in kindergartens. (T8) }\end{array}$ & 6 & 24.00 \\
\hline & $\begin{array}{l}\text { The necessity of } \\
\text { Pre-School } \\
\text { Education }\end{array}$ & $\begin{array}{l}\text { The importance and necessity of pre-school } \\
\text { education should be explained to all } \\
\text { segments of society. (T11) }\end{array}$ & 5 & 20.00 \\
\hline & $\begin{array}{l}\text { Compulsory Pre- } \\
\text { School Education }\end{array}$ & $\begin{array}{l}\text { Pre-school education should be made } \\
\text { compulsory. (T25) }\end{array}$ & 4 & 16.00 \\
\hline & $\begin{array}{l}\text { In-Service } \\
\text { Training of } \\
\text { Teachers }\end{array}$ & $\begin{array}{l}\text { Pre-school education teachers can be } \\
\text { provided with in-service training to increase } \\
\text { their qualifications. (T2) }\end{array}$ & 3 & 12.00 \\
\hline & Sourcing & $\begin{array}{l}\text { The budget allocated to pre-school education } \\
\text { should be increased. (T6) } \\
\text { By allocating a budget to pre-school }\end{array}$ & 3 & 12.00 \\
\hline
\end{tabular}




\begin{tabular}{|c|c|c|c|}
\hline & $\begin{array}{l}\text { Education, families can avoid making } \\
\text { expenses. (T13) }\end{array}$ & & \\
\hline $\begin{array}{l}\text { Having Lesson } \\
\text { Breaks }\end{array}$ & $\begin{array}{l}\text { It is necessary to take a break during the } \\
\text { training hours. (T10) }\end{array}$ & 2 & 8.00 \\
\hline $\begin{array}{l}\text { Increasing } \\
\text { Physical Facilities }\end{array}$ & $\begin{array}{l}\text { The physical facilities of schools should be } \\
\text { increased. (T9) }\end{array}$ & 2 & 8.00 \\
\hline $\begin{array}{l}\text { Teacher } \\
\text { Qualification }\end{array}$ & $\begin{array}{l}\text { It is necessary to organize training for } \\
\text { teachers. (T4) } \\
\text { Language education should be given to the } \\
\text { teachers during the candidacy process, and } \\
\text { foreign language education should be given } \\
\text { in the pre-school period. (T14) }\end{array}$ & 2 & 8.00 \\
\hline $\begin{array}{l}\text { Increasing the } \\
\text { Social Value } \\
\text { Given to the } \\
\text { Teacher }\end{array}$ & $\begin{array}{l}\text { In order to increase the social value given to } \\
\text { the teacher, some studies should be started } \\
\text { (T14). }\end{array}$ & 1 & 4.00 \\
\hline Class Sizes & $\begin{array}{l}\text { Class sizes should not exceed } 15 \text { students. } \\
\text { (T7) }\end{array}$ & 1 & 4.00 \\
\hline $\begin{array}{l}\text { Establishment of } \\
\text { Workshops }\end{array}$ & $\begin{array}{l}\text { Workshops should be established in schools } \\
\text { where children can have different } \\
\text { experiences. (T15) }\end{array}$ & 1 & 4.00 \\
\hline $\begin{array}{l}\text { Opportunity } \\
\text { Equality }\end{array}$ & $\begin{array}{l}\text { Equal opportunities should be provided in } \\
\text { education. (T13. }\end{array}$ & 1 & 4.00 \\
\hline $\begin{array}{l}\text { Regulation of the } \\
\text { School Starting } \\
\text { Age }\end{array}$ & $\begin{array}{l}\text { The starting age for pre-school education } \\
\text { should be regulated, and the age group, } 3-4 \text {, } \\
\text { should be included in pre-school education. } \\
\text { (T13) }\end{array}$ & 1 & 4.00 \\
\hline $\begin{array}{l}\text { Number of } \\
\text { Teachers }\end{array}$ & $\begin{array}{l}\text { Pre-school teacher quotas should be } \\
\text { increased in teacher appointments. (T8) }\end{array}$ & 1 & 4.00 \\
\hline $\begin{array}{l}\text { Improving } \\
\text { Teachers' } \\
\text { Personal Rights }\end{array}$ & $\begin{array}{l}\text { Teachers' personal rights need to be } \\
\text { improved. (T6) }\end{array}$ & 1 & 4.00 \\
\hline Form of Teaching & $\begin{array}{l}\text { Pre-school education should be carried out as } \\
\text { a single education. (T24) }\end{array}$ & 1 & 4.00 \\
\hline
\end{tabular}

When Table 7 is examined, the findings and comments regarding the question "What should be done for the development of pre-school education", which were asked to the teachers interviewed, were discussed. In this theme, expanding schooling, family education, meeting the material needs, and lack of auxiliary personnel are the most mentioned issues, with $24 \%$ when the answers are proportionate. When Table 7 is examined for the different findings related to the opinions of teachers about what should be done for the development of pre-school education, it is seen that the necessity of pre-school education is $20 \%$, pre-school education is compulsory $16 \%$, in-service training of teachers is $12 \%$, and resource provision is the most mentioned with $12 \%$. are understood to be issued. The necessity, of course, breaks, increasing physical opportunities, and the quality of the teacher appear as different issues that are mentioned at the same rate with $8 \%$. When Table 7 regarding this theme is examined, we encounter different teachers' views as increasing the social value given to the teacher with a rate of $4 \%$, class sizes, the establishment of workshops, equal opportunities, regulating the school starting age, number of teachers, improving the personal rights of teachers, and single education. Some of the teachers in the study group, who expressed their views on what needs to be done for the development of pre-school education, said:

“...Pre-school education needs to be expanded."T7

"...It is necessary to organize some activities in order to change the attitudes of parents towards pre-school education.”T23 


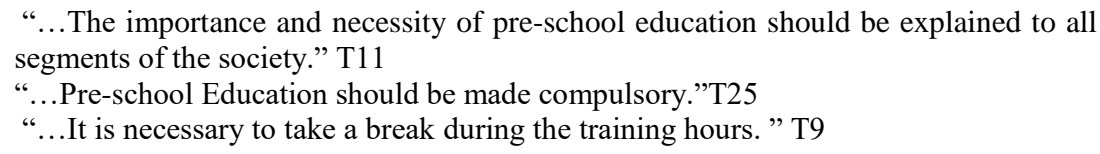

\section{Discussion and Conclusion}

\section{Evaluation of Policies in the Field of Pre-School Education}

Pre-school education takes place within the integrity of the primary education, which provides rich, stimulating environment opportunities suitable for the developmental levels and individual characteristics of the children in the 0-72 month group, supports their physical, mental, emotional and social development, guides them in the best way in line with the cultural values of the society and prepares them for primary education. It is an educational process that takes place (Şahin, 1998). The pre-school period is when learning is the fastest and most intense, basic skills and habits are acquired in all developmental areas, and cognitive abilities are rapidly developed and shaped (Arslan-Karakuş, 2008; Bee \& Boyd, 2009; Oktay, 2004). Meeting the needs of the child, supporting his/her development in all aspects and ensuring that he/she is prepared for life in the best way can be achieved with a qualified pre-school education that will be offered to him/her in these early years, and pre-school education is essential for the child's healthy development in all areas (Aslanargun \& Tapan, 2015; Gültekin-Akduman, 2015; Kalkan \& Akman, 2009). Many studies have been carried out on pre-school education policies in our country between 2000-2019 for the primary education of pre-school children.

As a result of the research, the interviewed teachers were asked, "How do you evaluate the policies in the field of pre-school education after 2000?" The positive opinions given to the question of the question were the spread of schooling, child-centred education, increasing physical opportunities, giving importance to pre-school education, education with games, family participation, providing resources, while the negative opinions were not providing enough financial resources, decreasing the social value given to the teacher, infrastructure problem in schools, personnel quality. Appears as the neglect of pre-school education.

\section{The Best Step Taken in the Field of Pre-School Education}

For pre-school education, each country takes various steps to gain social and cultural values. Regarding the inequality of opportunity in education, which is included in our country's 42nd article of the 1982 constitution, "No one can be deprived of the right to education and training, and the scope of the right to education shall be determined by law and regulation. Primary education is compulsory for all citizens, male and female, and is free in public schools." statements are included.

In addition, different support programs have been tried to be implemented for children from regions with a low socioeconomic level to ensure equal opportunity in education. However, it is seen that the importance of pre-school education in our country has been realized late compared to other countries and it has been tried to organize pre-school education with the policies made since 2000. However, knowing how much these studies are understood by the "teacher", who is the cornerstone of this educational process, and seeing how much they are reflected in practices is considered a process that should be done before creating a new policy.

"In your opinion, what is the best step taken in the field of pre-school education?" The participants, who were asked the following question, expressed their views on the necessity of pre-school education, the expansion of schooling, the preparation of pre-school education 
programs, the increase of pre-school education institutions, the number of personnel, the use of technology, family participation, child-centred education, and school-age regulation.

The issue of making pre-school education compulsory, which is the opinion expressed by many participants, has still not been made compulsory in the whole country as of 2019 . However, it is tried to be made compulsory with the applications made in the pilot provinces. Countries where compulsory pre-school education should be selected and examined and results should be revealed by conducting large-scale research on these countries' education. The Ministry of National Education (MoNE) should make the necessary legal arrangements as soon as possible to make pre-school education compulsory.

\section{Weaknesses of Pre-School Education Policies Developed Between 2000-2019}

It has been decided to switch to 'dual education' in official kindergarten classes to increase the schooling rate by $21 \%$ for $4-6$-year-olds. Although the child should receive a halfday education for a year before starting primary education, dual education should not be a permanent solution. 70\% of the respondents to the questionnaire applied on the MoNE website stated that they found the dual system "positive". However, a study conducted on this subject determined that the social-emotional development of children who received half-day education was lower than those who received full-time education (Özguluk, 2006). Based on this result, it can be assumed that half-day education will prevent the child from reaching the desired level in other areas of development.

Pre-school education in Turkey is mainly given in kindergartens within primary schools. Almost all of the administrators, who are also responsible for the kindergarten classes of these schools, are outside the pre-school education field. When we look at the feedback received from the teachers in this study, it is seen that the administrators do not understand the importance of pre-school education enough, and they are reluctant to meet the needs of the kindergartens. However, Kurt (2015) examined the cooperation skills of pre-school education institution administrators, and it was found sufficient by the teachers in terms of cooperation skills of administrators and interpersonal communication skills. However, it is known that almost all of the inspectors in charge of inspecting pre-school education institutions are from outside the field. In-service training given to administrators and supervisors for pre-school should also be given by experts in their fields and should be continued increasingly. Pre-school education graduates who can fulfil the necessary conditions should also be supported to become managers and supervisors.

The participants were asked, "What are the deficiencies of the pre-school education policies developed between 2000-2019?" When we examine the answers given to the question of family education, lack of materials in the classrooms, class sizes, pre-school education is not compulsory, the difficulty of the implementation of the program, the lack of physical opportunities, the lack of auxiliary personnel, the lack of resources, the decrease in the social value given to the teacher, the absence of class breaks, the lack of teachers' rights. Neglecting pre-school education, providing financial resources, the necessity of pre-school education, early school starting age, equality of opportunity, educational status of administrators come to the fore. Similarly, Simsar (2021b) emphasized in his study that families should take a role in preschool education with training to be organized for families. Likewise, Yazır, Çelik, and Kök (2008) emphasized that the first education should be given in the family in the pre-school period and stated the critical role of the family in pre-school education. However, Doğan, Yalçın, and Simsar (2017) emphasized in their study that there are not enough resources and materials to support a vital learning process, such as science activities in some pre-school classrooms. The new policies to be developed must focus on providing materials to the classes. 


\section{Things to be Done for the Development of Pre-School Education in Our Country}

Ask them, "What should be done for the Development of Pre-School Education in Our Country?" teachers asked; dissemination of schooling, family education, eliminating the need for materials, lack of auxiliary personnel, the necessity of pre-school education, compulsory pre-school education, in-service training of teachers, providing resources, taking breaks, increasing physical opportunities, teacher qualification, increasing the social value given to teachers, They answered that class sizes, the establishment of workshops, equality of opportunity, regulation of school starting age, number of teachers, improvement of teachers' personal rights, regulation of teaching style are necessary. Similarly, Özkubat (2013) stated in his study that the quality of pre-school education environments should be improved, and the education to be given in the classrooms and the development of children should be supported.

In the 27th article of the MoNE Pre-School Education Institutions Regulation, it is essential to have a doctor who is an expert on child health in pre-school education institutions (MoNE, 2006). In the absence of a school doctor, government doctors, health centres, health education centres, if any, mother-child health centres and similar institutions are used for health services. Pre-school children are vulnerable to accidents because they cannot fully protect themselves. In addition, considering disaster situations such as earthquakes and fires, since there is no doctor in charge in every institution, administrators and teachers working in pre-school education institutions should be knowledgeable about first aid and emergency response. It is recommended that teachers who do not have sufficient knowledge on this subject be trained through in-service training and courses organized by non-governmental organizations.

In the transition from kindergarten and kindergarten to primary education, the physical environment and classroom rules differ with sharp lines, and there are plenty of toys in preschool education institutions, a comfortable seating arrangement and flexible rules; On the other hand, the fact that the first grades of primary education are without toys and mainly in a row order creates serious adaptation problems for some of the children who start the first grade. Arranging the physical characteristics of the first grades of primary education similar to kindergarten and kindergarten classes and applying the rules more flexibly will reduce the adaptation difficulties of children who have just started school.

In the pre-school period, which forms the basis of an individual's life, the child acquires essential habits, interacts with his environment, socializes, and develops cognitive and affective skills and abilities. The opportunities and adult support to be given to the child during this period will ensure that the child is best prepared for life; Depriving the child of this support will cause him to encounter many difficulties in preparing for life. For this reason, pre-school teachers teach that children in the pre-school period are curious, willing to research, and have broad imaginations; Supporting the development of children in this direction can support their development by providing educational environments where they can research and question, develop their curiosity, establish cause-effect relationships and make predictions (Beaty, 1988). In order to achieve this situation, the importance of the programs to be developed in pre-school education is very high.

\section{Recommendations}

As a result of this research, teachers' policies in the field of pre-school education; widespread schooling, child-centred education, increasing physical opportunities, giving importance to pre-school education, education with games, family participation, providing resources, opposing opinions, insufficient financial resources, decrease in the social value given to teachers, infrastructure problem in schools, personnel quality, not caring about pre-school 
education as they appeared. In this regard, introductory activities can be organized by the Ministry of National Education so that pre-school education policies are understood by preschool teachers who are the implementers of these policies.

As it is known, lesson hours and break times are fixed in primary education, and there is a duty teacher application. In pre-school education, on the other hand, teachers are required to spend all their time in the institution with children. It is beneficial to have at least one assistant teacher, depending on the institution's availability, to rest the teachers at certain intervals and support them when needed (children with special education needs, excursions, emergency, accident, etc.). What is meant here is not the duty teacher practice in primary education institutions.

It is necessary to take teachers' opinions at the highest possible rate during the preparation of laws, regulations and by-laws in various scientific studies and published reports, National Education Councils, Development Plans, which are at the stage of determining education policies.

Various non-governmental organizations, public institutions and organizations, etc. An awareness of pre-school education can be created in the country by explaining the importance through several activities prepared jointly with groups.

\section{References}

Albrecht, K. \& Miller, L. (2004). The comprehensive pre-school curriculum. Maryland: Gryphon House, Beltsville.

Alisinanoğlu, F., Kesicioğlu, O. S., \& Ünal, E. (2010). Okul öncesi öğretmen adaylarının mesleki kayg1 düzeylerinin incelenmesi [Examining the professional anxiety levels of pre-school teacher candidates]. International Symposium of Policies and Issues on Teacher Education. Hacettepe University, Ankara.

Aral, N., Kandır, A. \& Can Yaşar, M. (2003). Okul öncesi eğitim [Early Cildhood Education] ( $2^{\text {nd }}$ ed.). İstanbul: Ya-Pa publishing.

Arslan-Karaküçük, S. (2008). Okul öncesi eğitim kurumlarında fiziksel/mekânsal koşulların incelenmesi: Sivas ili örneği.[ Examination of physical/spatial conditions in pre-school education institutions: The case of Sivas province.] Sosyal Bilimler Dergisi [Journal of Social Sciences], 32(2), 307-320.

Aslanargun, E. \& Tapan, F. (2015). Okul öncesi eğitim ve çocuklar üzerindeki etkileri. [Preschool education and its effects on children.] Abant İzzet Baysal Üniversitesi Ë̆itim Fakültesi Dergisi [Journal of Education Faculty of Abant İzet Baysal University], 11(2), 219-238.

Beaty, J. (1988). Skills for pre-school teachers. Columbus: OH: Merrill.

Bee, H. \& Boyd, D. (2009). Çocuk gelişim psikolojisi [Child Developmental Psychology]. (Trans. Gündüz, O.) İstanbul: Kaknüs Publishing.

Bekman, S., \& Gürlesel, C. F. (2005). Doğru başlangıç Türkiye'de okul öncesi eğitim: Özet bulgular [The right start Pre-school education in Turkey: Summary findings]. TÜSİAD Publishing.

Doğan, Y. , Yalçın, V. \& Simsar, A. (2017). Okul öncesi sınıflarındaki fen merkezleri ve kullanım durumlarının incelenmesi-Kilis örneği [Examination of science centers in preschool classes and their usage cases-the case of Kilis]. Kilis 7 Aralık Üniversitesi Sosyal Bilimler Dergisi [Journal of Social Sciences of Kilis 7 Arallk University], 7(14), 147164. doi: 10.31834/kilissbd.354745

Gültekin-Akduman, G., Günindi, Y., \& Türkoğlu, D. (2015). Okul öncesi dönem çocukların sosyal beceri düzeyleri ile davranış problemleri arasındaki ilişkinin incelenmesi. 
[Examination of the relationship between social skill levels of preschool children and behavioral problems ]. Journal of International Social Research, 8(37). 673-683.

Kalkan, E., \& Akman, B. (2009). Examining pre-schools' quality in terms of physical conditions. Procedia-Social and Behavioral Sciences, 1(1), 1573-1577.

Kurt, S. (2015). Okul öncesi eğitim kurumu yöneticilerinin iletişim beceriler [Communication skills of preschool administrators]. (Unpublishing master's thesis). Çanakkale University, Institute of Education, Çanakkale.

Ministry of National Education (MoNE) (2006). Okul öncesi eğitim programı (36-72 aylık çocuklar için) [Pre-school education program (for 36-72 months old children)], Ankara.

Oktay, A. (2004). Yaşamın sihirli yılları: Okul öncesi dönem [Magic years of life: Pre-school period]. İstanbul: Epsilon Publishing.

Özgülük, G. (2006). Okul öncesi eğitim kurumlarında tam ve yarım günlük eğitim programlarına göre 5-6 yaș grubu çocuklarının sosyal duygusal gelișimlerinin incelenmesi [Investigation of social and emotional development of 5-6 year old children according to full and half-day education programs in pre-school education institutions]. (Doctoral dissertation). Marmara University, İstanbul.

Özkubat, S. (2013). Okul öncesi kurumlarında eğitim ortamlarının düzenlenmesi ve donanım. [Arrangement and equipment of educational environments in pre-school institutions.] Adnan Menderes Üniversitesi Eğitim Fakültesi Ĕgitim Bilimleri Dergisi [Journal of Education Faculty of Adnan Menderes University], 4(2), 58-66.

Santrock, J. W. (2012). Ergenlik [Puberty] . Nobel Akademic Publishing

Simsar, A. (2021a). Young children s ecological footprint awareness and environmental attitudes in Turkey. Child Indicators Research, 14(4), 1387-1413. doi: 0.1007/s12187021-09810-7

Simsar, A. (2021b). An analysis of the views of parents with pre-school children about science and pre-school science activities. International Journal of Research in Education and Science, 7(2), 383-399. doi: 10.46328/ijres.2145

Şahin, E. (1998). Bursa ili merkez ilçelerinde okul öncesi eğitim kurumlarında görevli ögretmenlerin mesleki yeterliliklerinin belirlenmesi [Determination of the professional competencies of teachers working in pre-school education institutions in the central districts of Bursa]. (Unpublished master's thesis). Gazi University, Institute of Social Sciences, Ankara.

Yazar, A., Çelik, M., \& Kök, M. (2008). Aile katılımının okul öncesi eğitimde ve 2006 okul öncesi eğitim programındaki yeri [The place of family participation in pre-school education and 2006 pre-school education program]. Atatürk Üniversitesi Sosyal Bilimler Enstitüsü Dergisi [Journal of Social Sciences Institute of Atatürk University], 12(2), 233-243.

Yıldırım, A., \& Şimşek, H. (2013). Sosyal bilimlerde nitel araştırma yöntemleri [Qualitative research methods in the social sciences] Ankara: Seçkin Publishing. 